\title{
Beholding Tanjung Pesona Coastal-ecotourism in Bangka Islands, Indonesia
}

\author{
Hengky, S. H. \\ Bina Darma University, Director of Kent Polytechnic, Shine Institute, Indonesia \\ Email: hengky_halim@yahoo.com.au
}

Received: May 30, 2017 Accepted: June 21, 2017

doi:10.5296/ber.v7i2.11552ＵRL: https://doi.org/10.5296/ber.v7i2.11552

\begin{abstract}
Tourism sector becomes the largest foreign exchange contributor in 2020, and Indonesia has a number of tremendous natural and cultural potential to become a national tourism development asset. Even this potential could be a reckoned contributor to GDP, Foreign Exchange, and Employment. This study aims to respond Deputy of Business Market Segment and Government of Ministry of Tourism, and to behold Tanjung-Pesona coastal ecotourism. However, this fieldwork results show that the existing performance is in critical condition based on coastal-ecotourism. There are three main issues that should be addressed immediately. Firstly, enhancing community education on handling fragile ecosystems. Secondly, local government got to improve the performance of coastal carrying capacity, as well as sustaining local business model. Thirdly, they get to increase an incentive for supporting coastal environment protection program that would reduce carbon footprints and made it based on collective action. It would maintain the levels of financial stability too. The final solution of the local government to make the zoning of tourism, mining. In addition, there is the potential for regional culinary-ecotourism and fishing-ecotourism that can make a vibrant coastal-ecotourism in the islands. Besides, there are many traditional culinary options that can contribute economic to local people as sustainable local-business models. It's a unique food.
\end{abstract}

Keywords: Coastal-ecotourism, Culinary tourism, Fishing tourism, Traditional culinary

\section{Introduction}

Bangka-Belitung Island is a province that name is taken from two islands of Bangka and Belitung. It has long been known as the largest tin producer in Indonesia and it has an amazing coastal nature charm. In addition, there are also small islands such as Lepar-Island, Pongok-Island, Mindanao-Island and Nasik-Strait Island. All islands that has been named are only 50 of 470 islands. The island is one of a tourism place that has a variety of interesting 
attractions as several diving spots, beautiful coastline charming, various food choices, and city tours past. Generally, the beaches have soft sand, slopping beaches, crystal clear waters, an enchanting collection of granite stones, and beautiful diving spots. The islands have a tropical climate influenced by monsoon winds. It has a wet month for seven months throughout the year and a dry month for five months continuously.

The island is located on the east coast of southern Sumatra that is $1^{\circ} 20^{\prime}-3^{\circ} 7$ South Latitude and $105^{\circ}-107^{\circ}$ East Longitude. It's extending to West Sea to Southeast along $180 \mathrm{kms}$ approximately. The island consists of swamps, low land, hills and hilltop. There are dense forests, and in the swamp area that tourists could enjoy mangrove forests. The swamp of the island is not so different from the island of Sumatra. The specialty of the beach compared with other areas is a slopping white sandy beach with decorated granite rocks. The beach offers tourists for marine tours such as diving, snorkeling, fishing and sailing. One of the most famous beaches in the island is Tanjung-Pesona beach. It located in the center of Bangka regency. It about 9 kilometers from Sungailiat town center. This beautiful city is also the capital of the district. Administratively and geographically, this beach is included in the area of Rambak Village. The tourists can enjoy the beauty of this beach clearly backed by a hill.

Assistant Deputy of Development of Business Market Segment and Government of Ministry of Tourism, said that Indonesia is a rich country in natural and cultural potential. These are an asset for the development of national and international tourism. Tourism sector was projected to exceed other sectors that now excel, such as oil, gas and coal. By 2020, tourism sector would be the largest contribute foreign exchange, because Indonesia has tremendous natural and cultural potential destinations that become a national and international tourism development asset. Even this potential could be the biggest contributor to the GDP, foreign exchange and employment (Yanuar, 2017).

This study aims to respond Deputy of Business Market Segment and Government of Ministry of Tourism, and to behold Tanjung-Pesona coastal ecotourism in Bangka islands.

\section{Literature Review}

Ecotourism is an alternative to sustainable coastal tourism towards more exploitative forms of economic development and refers to the ethnographic side of coastal communities. By analyzing the collective action, resistance of organizations and indigenous peoples to territorial autonomy, there is a close relationship between extracting industries and traditional tourism. This action relies on a community-based takeover of natural resources, enclosure and repossession that result in widespread environmental degradation and ecological unrest for indigenous peoples in the coastal areas. Neoliberal tourism policies are using ecotourism and sustainable development as a cover, and It's creating conditions for extracting to survive in the region (Whitney, 2017; Chien, 2016; Loperena, 2016; Porter, Orams, and Lück, 2015; Boscolo et al., 2011; Sakata and Prideaux, 2013).

The development and expansion of tourism areas is complex phenomenon and they need to be studied interdisciplinary. Currently, coastal tourism's development is increasing rapidly. In 
this case, the growth and expansion of the tourism area has a close relationship between sustainability, the limits of tourist growth, and carrying capacity. These three aspects must be considered in the management of coastal tourism. Management of coastal tourism in sustainability using the concept of carrying capacity. There are four beach tourism activities are appropriate, namely beaches, snorkeling, diving, and mangrove tourism (Nuzula, Armono, and Rosyid, 2017).

The adaptation of coastal communities to climate change impacts that include sea level rises, increased severity, and frequency of these storms. They are included in coastal tourism management planning efforts by using the river ecosystem landscape. This program is proof the concept, and demonstrating collaborative design. It can improve the ability of coastal areas in many areas to recover from storms and sea level rise. It's using the broad concept of ecological and geomorphological structures. These ecological relationships were maintained or restored from sand beaches through tidal bays to the mainland. This allows species to migrate to the mainland, because their ecosystems change from time. The program is also becoming beach tourism attraction. It would attract tourists to visit and enjoy the natural beauty to the greater and broader coastal areas. The program becomes an approach that can sustain or even increase social and economic activity along sea level changes.

Transport routes connecting shorelines that are changing into rural areas help to integrate social activities across the region. This watershed-based program can handle rainwater runoff from severe inland storms as well as needed. These principles can be applied to any coastal landscape where expected sea level rises. This approach is nurtured and supported by rebuilding and designing a program - to combine unique, collaborative, architectural and ecological approaches to climate change and sea level in storm-affected areas. This ecological concept can be adapted to use in order to maintain biotic and economic processes of coastal communities (Attemene and Eguavoen, 2017; Burgera, O'Neillb, Handelc, Hensoldd, and Fordd, 2016; Almeyda, Broadbent, Wyman, and Durham, 2010; Diamantis, 2000; Picard, 2007).

The natural beaches are strategic for an ecological location. Based on the criteria for assessing the potential for coastal ecotourism, coastal boundaries are identified as coastlines and the maximum range of water approach to the ground and taking into account the characteristics of nearby coastal villages. Similar international criteria and experience are compared with original criteria, then divided into three main criteria and four sub criteria. The potential for the coastal tourism industry high in the region. It needs to be at the level of its quality to be coastal ecotourism and supported by environmental management plans for coastlines that become very important (Pace and Morgan, 2017; Krause and Weir, 2011; Nouri, Danehkar, and Sharifipour, 2008).

The development of coastal ecotourism provides an adequate economic incentive to prevent ecological resource extraction problems. Global demand encourages extreme exploitation of natural resources in ecologically sensitive locations. As a guarantee of future generations, countries are tested for their commitment to sustainable development. The exploitation threatens the socio-environmental dynamics that supported sustainable development in a 
country. It relies on coastal ecotourism with circumstances that demonstrate a commitment to environmental protection. Strong environmental protection regime would be built by combining the utilization of natural resources into a cruise-based mass-based tourism economy together with the exploitation of natural resources further eroded incentives (Gould, 2017; Picard, 2015).

Coastal ecotourism attraction has unique location of biodiversity including the world's largest intact coral reefs, and greater implications for the willingness and capacity of countries, private capital, and local communities to protect the ecosystem and a growth-dependent global economy. Utilization of these natural resources shifts the economic-political dynamics underlying efforts to build and maintain a more sustainable development path. The combined efforts of conservation organizations and private capital based eco-tourism have provided a counterweight to the full reorientation of development strategies (Sakata and Prideaux, 2013; Virapart, 2011; Lloret, and Riera, 2008).

The current management of the international tourism industry as a significant contributing factor of global warming. The implications come from large-scale enterprises that include lodging facilities in the tourism context. It's responsible for damages resource such as depletioning and pollution. New trends in tourism demand habits that are concerned with the natural environment. It has enabled an emerging tourism industry segment. Maintaining the carrying capacity of the environment, these tourism activities are believed to be significantly less dangerous and very helpful. Ecotourism benefits to reduce carbon footprints, sustainable local business models, broad community education on fragile ecosystems, and increased levels to strategic financial stability. The nature of ecotourism suggests an incentive to increase environmental protection that is weighed against possible negative impacts. Coastal ecotourism has a positive and sustainable solution to environmental degradation that caused by the international tourism industry (Michael, 2017; Cobbinah, 2015; Doyon and Sabinot, 2014; Krause and Weir, 2011; Kelkit, Celik, and Esbah, 2010; Phillips, 2007).

However, coastal-ecotourism is tourism activities that helpful in maintaining the carrying capacity of the coast environment. It contributes incentive to increase environmental protection. Besides, it benefits to reduce carbon footprints, sustaining local business, broader community education on fragile ecosystems, and increased levels to strategic financial stability (Michael, 2017; Cobbinah, 2015; Doyon and Sabinot, 2014; Krause and Weir, 2011; Kelkit et al., 2010; Philips, 2007).

\section{Methodology}

This qualitative and quantitative investigation (Jenning, 2001) were arranged from March 2015-March 2016 in Tanjung-Pesona (Figure 1). 280 questionnaires were spread purposive to: tour guide, and tour operator. Besides, it distributed among hotel and restaurant staffs, tourists, guests. Moreov, this study also asked the questionnaires to tourist's bus driver, and travel agent. Finally, it was questioned to Department of culture and tourism, merchant of local traditional food, souvenirs' seller, local community, parking attendants, and tourist associations. 


\section{MInstitute Macrothink $_{\text {Int }}$}

The collected data was enumerated by using content analysis (Gottschalk, 2013; Henderson, 1991; Cohen, 1960), based on the concept of coastal ecotourism. Its pivot on maintaining the carrying capacity - environment, increased incentive to environmental protection, benefits reduced carbon footprints, sustainable local-business models, broad community education on fragile ecosystems, and increased levels to financial stability (Michael, 2017; Cobbinah, 2015; Doyon and Sabinot, 2014; Krause and Weir, 2011; Kelkit et al., 2010; Philips, 2007).

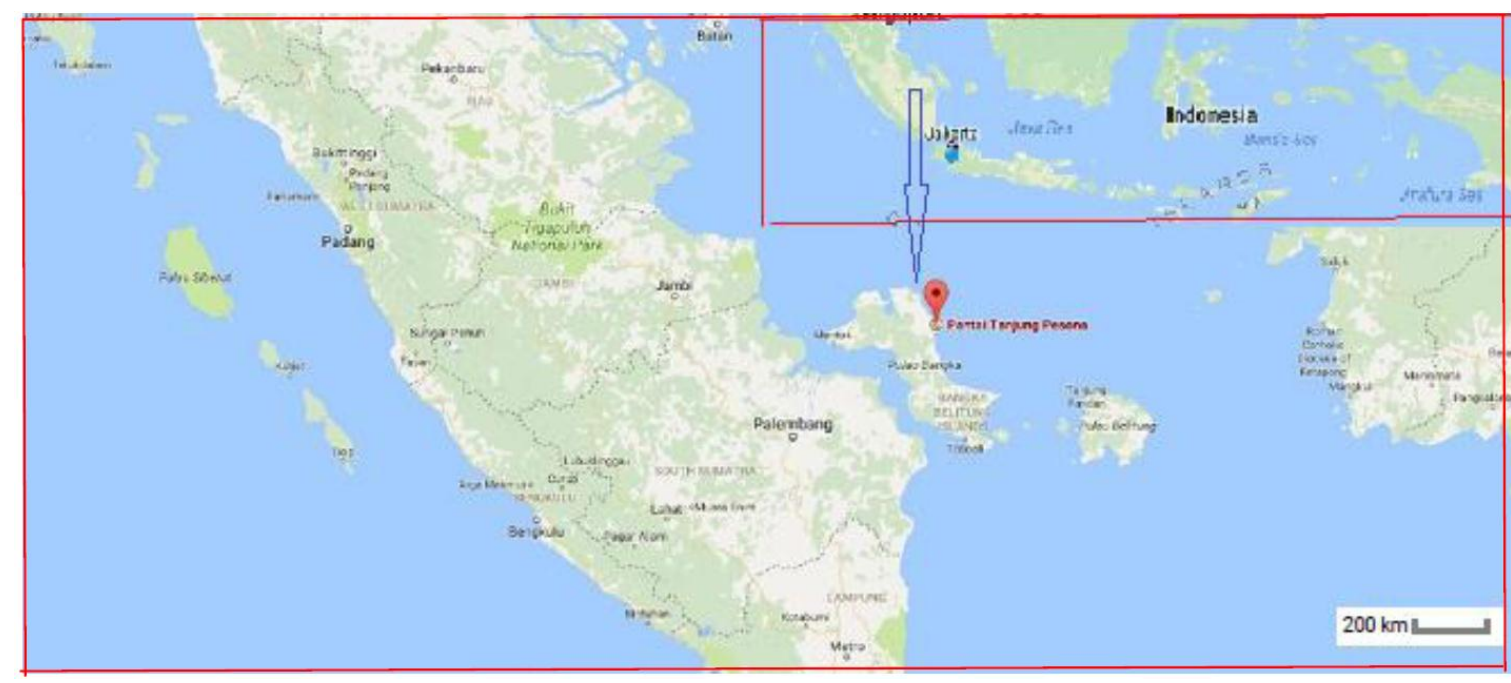

Figure 1. Tanjung Pesona Beach

Data collected was emphasized by using triangulation techniques. It's invigorating an observation, open interview, secondary data for substantiating (Marwick and Uniger, 1975). In terms of topics, interest, and opinions or a view of respondent, interview outcomes were significantly leveraged by the circumstance of the interviewer. In brief, the upshot of the content analysis proceeds with coastal-ecotourism explore dissent, posting each attribute, frequency counted, and argue for existing and targeting performance (Pace and Morgan, 2017; Nuzula et al., 2017; Loperena, 2016; Krause and Weir, 2011; Nouri et al., 2008).

\section{Results and Discussions}

This fieldwork results show that Tanjung-Pesona existing performance (Table 1) is in critical condition $\left(\mathrm{K}_{1}=0.5963\right)$. Based on the concept of coastal-ecotourism, there are three main issues that should be addressed immediately. Firstly, enhancing community education on handling fragile ecosystems (Frequency $=0.1429)$. Secondly, local government got to improve the performance of coast's carrying capacity (Frequency $=0.1553$ ). Finally, they get to sustain local business model (Frequency $=0.1615$ ). Thereafter, to fulfil the expecting performance of coastal ecotourism (Table 2) and based on collective action, they get to maintain the carrying capacity (Frequency $=0.1777$ ), and they get to increase an incentive for supporting coastal environment protection program (Frequency $=0.1675$ ) that would reduce carbon footprints $($ Frequency $=0.1827$ ). It would maintain the levels of financial stability (Frequency $=0.1574)$. 
Table 1. Existing performance of Tanjung Pesona Coast

\begin{tabular}{|l|c|c|}
\hline Existing Coastal ecotourism in Tanjung Pesona & Value & Freq \\
\hline Maintaining the carrying capacity - environment & 25 & 0.1553 \\
\hline Increased incentive to environmental protection & 28 & 0.1739 \\
\hline Benefits reduce carbon footprints & 29 & 0.1801 \\
\hline Sustainable local-business models & 26 & 0.1615 \\
\hline Broad community education on fragile ecosystems & 23 & 0.1429 \\
\hline Increased levels of financial stability & 30 & 0.1863 \\
\hline Kappa Coefficient $=\mathbf{K}_{\mathbf{1}} \mathbf{\mathbf { 0 , 5 9 6 3 }}$ & & \\
\hline
\end{tabular}

Table 2. Expecting performance of Tanjung Pesona Coast

\begin{tabular}{|l|r|c|}
\hline Expecting Coastal ecotourism in Tanjung Pesona & Value & Freq \\
\hline Maintaining the carrying capacity - environment & 35 & 0.1777 \\
\hline Increased incentive to environmental protection & 33 & 0.1675 \\
\hline Benefits reduce carbon footprints & 36 & 0.1827 \\
\hline Sustainable local-business models & 30 & 0.1523 \\
\hline Broad community education on fragile ecosystems & 32 & 0.1624 \\
\hline Increased levels of financial stability & 31 & 0.1574 \\
\hline Kappa Coefficient $=\mathbf{K}_{\mathbf{2}}=\mathbf{0 , 7 2 9 6}$ & & \\
\hline
\end{tabular}

Recently, Tanjung-Pesona is one of the natural beach. They are maintaining the carrying capacity of the beach line of this island is beauty. As the name implies, this beach makes a fascination for any visiting tourists. Beautiful beach on the island is equipped with adequate facilities that support the tourism sector there. Therefore, the tour operator and local government got to maintain the environment along the coastline. In addition, when viewed from the south side, tourists can also see the charm of Bangka Island that has been collected on the beach. Blue sea water, white sand beach, and typical granite rocks of this island combined with a number of cottages built facing the beach. The tourists usually do not waste the beauty of Bangka Island in the afternoon. It was covered by rainy season clouds. The evening sun occasionally showed its rays of the sea of the Beach. Presents beautiful scenery, namely sea watered sparkling because of the reflection of sunlight (Law, 2014).

A bridge that has become the identity of Tanjung-Pesona Beach can be an interesting attraction for travelers. They can walk towards the bridge to cross to a small hut built at the end of the bridge. From the cottage, they can feel the charm of another Cape Coast Charm. It was as if they were in the middle of the sea just off the taste. After that, they can get around to the other side of the Beach, climbing one by one of the granite rocks piled up against the east sea waves of the island. Some tourists finally reached the north side of the beach. On the side that faces this Uber Bay Beach, granite rock with a lot of strands we can see a wonderful view.

Admittedly the beauty of the beach on this island, there is no end to it. The local government 
and travel agency could use this famous city increased levels of financial stability. The city is one of the cleanest cities in Indonesia. It was proven by having twice to win award in 1997 and 2005. It's located in the capital city of Bangka regency, which is less than one-hour drive by car from Pangkal-pinang scattered beaches is quite beautiful. In the city, there is Tanjung-Pesona Beach, which is about $9 \mathrm{kms}$ from the city. This beach is in the middle of nowhere between Uber Bay Beach and Rat Coast. Admittedly this beach has a panoramic view of the open sea, on a headland with large rocks. Uniquely, these stones forms like a fortress that keeps this beach from invading the sea. Not only that, this beached is also included in the location of the hotel with three star facilities. The panoramas provided by the hotel add to the convenience of the tourists that come here. In addition, there are extensive facilities such as Cottages, Restaurant, Karaoke, Discotheque, Billiards, Children's Games, and car park. It is often held show to entertain the tourists. Unfortunately, the offered scenery is disrupted by the garbage scattered not cleaned in some places.

On the other hand, there is a spatial-planning issues of sustainable local-business models. This situation is exacerbated by the control of land around the coast by investors. They build hotels and resorts and occupy the beach only for its guests. The atmosphere is visible from this beach. To enjoy the beautiful beach, visitors must enter the resort area and through the guard post with the door barred. The beach is supposed to be a public area that is currently restricted and as it is served only to the guests who stay at the luxury hotel. With the existence and operation of various hotels and resorts to the area, the formerly beautiful and gently slopping coast is now a mess, full of gap holes. The formerly clean white sand, now it becomes a blackish's brown due to the mixed mud of tin mining waste. In addition, the original sea water is turquoise-blue has also turned into dirty-brownish and smelly. Some of the pavilions built for tourist facilities seem less well maintained. In fact, this beach was once beautiful. Every holiday and weekend, many people visit the word local residents.

It is clear that factual existing condition of the island that could decrease a benefit of reducing carbon footprints. This study observed in its entirety. The island is also surrounded by suction vessels and unconventional floating mines. Besides being surrounded by a vast coral reef ecosystem. Around the exotic island with the local wisdom of its people was only able to keep the island's terrestrial ecosystem. The coral reef ecosystems surrounding it cannot be saved, because of the trend of tin mining is on the rise. The results of the checks are very disappointing, the coral cover on the south side of the island are only $14.54 \%$ with coral cover dead due to sediment $72.39 \%$. The rest is algae cover dominated by Padina, Coralite Alga, sea urchin (Diadema sp) and bleaching reefs due to the effect of temperature rise during the last few days of expedition. Conditions around them not much different.

Nevertheless, the government get to align their regulation on coastal tourism to become coastal ecotourism to increase the incentive to environmental protection. It would have increased the incentive to the coastal environment protection. They could maintain the coastal environment and do it based on collective action as well. Recently, there is a dilemma of the environment, the high diversity coral reefs around the island. Right now, it becomes worse. In fact, tourists a little bit hard to meet and to see 'Tridacna Squamosa' which is a protected giant shellfish. Recently, the ecosystem in the sea of this island is being followed to the damage that is not 
much different. The number of floating suction boats is growing and almost uncontrollable. Marine mining does not recognize the coral areas are still in good condition or marine tourism areas such as those that occur around this beach.

Furthermore, there is one day the tin mining business on the island. Right now it is no longer potential. Two of four leading sectors of the island to be developed in this area to support local people are fisheries and coastal tourism. The backbone of these two sectors actually becomes one with the coral reef ecosystem. From one square $\mathrm{km}$ of healthy coral reefs, it can produce 20 tons of fish (Burke, Reytar, Spalding, and Perry, 2011). This is enough to feed 1,200 people in coastal areas each year. Beautiful healthy coral reefs will be the main attraction of local and foreign tourists to travel. The higher diversity coral reef ecosystem in the subtropical region becomes a magnet for foreign tourists visiting coral spots in Indonesia (Ambalika and Septiawan, 2012).

The beauty of coral reef ecosystems and small islands in the waters around the island. Now it threats hit the potential for fisheries and marine tourism of the future of this region. In terms of broad community education on fragile ecosystems, the case of PT Timah's public company. Previously, they have conducted an environmental impact assessment process of mining in the Sea. Right now, they left an environment problem. They work on the area of approximately 30 thousand hectares covering the sea in several sub-districts on the island by operating on 12 production suction vessels in cooperation with partners. The main issue indicated that there is great potential for tin of the sea that includes the waters of the island. The current reality, with the destruction of coral reef ecosystems that are clearly happening in front of the eyes every day. It develops a question arises: What kind of sector would they like to prepare for the future generation of this island after the triumph of tin mining later? Local governments should immediately create a program to save this valuable ecosystem's degradation. Waiting and waiting for a wiser local government policy on this still-abandoned natural resource (Khoiri and Indriasari, 2010).

Based on experience and reality, tin mining will ultimately benefit mining miners and mafia mines. Meanwhile, society in the end only tasted bitter of the large potential for tin waste. It creates a few horizontal conflicts between communities to irreplaceable ecosystem damage. Meanwhile, the benefits are most felt by entrepreneurs, companies and officials who play the eye with this mining activity. The local government should be wiser to develop the East Belitung become more environmentally sustainable and for the welfare of its people. It built with a host of potential and environmentally friendly passions for the people of this region. Besides, if a corruption of local government apparatus was not supported by political intervention. It would have made the island become the second Brunei-Darussalam.

Moreover, the government tried to enhance maintaining environmental performance by increasing the incentive to environmental protection, even the business was not optimal yet. The impact on the activity of suction vessels in the waters around the island, now it began to be felt by fishermen, who originally pro mining in the sea. The indicator, they had received compensation for the mining of a number of suction boats previously, but now, they began to complain about the reduced catch of their catch. Not only that, the mining waste of suction 
vessels has caused few problems of the fishermen. There have been occasions for fishing boats that drowned in dried reef waters have killed 4 fishermen. This is apparently due to the mining waste of suction vessels in the form of piles of sand produced by suction vessels. This pile of sand has made land in the middle of the sea. When at night or sea watered in pairs. The pile of sand is also not seen by fishermen, so the fishing boats often bumped into it and overturned.

This is like the recognition of the coastal fishermen community figure, that they confirm the fishermen to react refusing the activity of mining the suction vessel. It increasingly rampant in the territorial waters of the island. From the confession of the survivors, the ship accident was caused by the fisherman's boat crashing into the waste of the suction vessel. It formed a pile of sand that it could not see by the fishermen at night. They also hoped that the suction shipped businessman to pay attention to this issue. Due to the pile of sand waste, it is very disturbing the activities of fishermen in the sea. Furthermore, they also regretted the activity of mining the suction vessel is very close to the catchment area of the fishermen. As a result, they often succumbed and caught fish twice as far from the distance as before. Previously, they went to a sea with a distance between 4 miles from the beach, but now it can be more. It caused of disturbed mining activities. So a fish has moved further into the middle of the ocean (Nikada, 2011).

After a year more, suction tin mining-vessels in the Sungailiat sea give their compensation for some fishermen. They did not provide welfare of them. From the signing of the contract with the suction vessel businessmen, fishermen already felt it was not able to improve their life. The results given from the compensation fund are not commensurate with their result. The compensation has been distributed three times among them with varying quantities. For the third compensation to 3,000 fishermen, they earn USD 15 per fisherman. Furthermore, second disbursement fell down to USD 8 per fisherman. The contract agreement stated that they gave USD 0.8 for each $\mathrm{kg}$ to them and it was depended on the results of tin mining company.

Moreover, following up the aspirations of all fishermen, they feel the mining project of suction vessels had not profitable to them. They are very disturbed once, especially the wind blows so strong. It is usually fishermen at sea with close range of 3-4 miles from the coast, and right now, it cannot be done anymore. To go to sea alone, fishermen need to double from the previous distance. The fisherman leaders asked a regent to stop immediately the activity of the suction vessel in the sea. Until now, it has not received a response yet from the regent regarding the request. They are very hopeful that the local government hear their aspirations of the community and fishermen stop their activities of mining the suction vessel. They feel mining activities did not profitable for a year. The fishermen began to complain about the decrease in their catch.

Furthermore, there is also a Minneapolitan area program to increasing levels from financial stability. It namely the conception of marine-based economic development based on the principles, efficiency, and quality. This program targets made fishermen more prosperous fish caught. It certainly more to compare it to mining that only benefits of a number of parties 
only a few of these fishermen from different regions comes to the islands. They are usually fishing and catch many fishes. They can be snapper (L. Campechanus), stingray (Dasyatis Americana), mirror fish (Carangidae, sp), fish thorns Gagok (Netuma Thalassina), fish Sembilang (Plotosidae sp).

Nevertheless, there are many culinary options that can be found by tourists in Bangka Belitung as sustainable local-business models. This unique culinary ecotourism would be other sustainable local-business models. Tourist can get it by visiting local merchandise as Acau-Martabak to taste the delicious original Martabak. People of Chinese descent from this area. There are famous culinary and wet cakes, noodles Bangka, Martabak-Bangka or Hok-Lopan or Van De Cock, Ca Kwe and many other types of food. They often sale it by these community groups that migrate to the big cities outside the province. Local merchant sales a coffee. There is one of thousands coffee shops spread across the various corners of this area. One of the most legendary is the Coffee Shop and Tung-Tau roast bread. The stall was established since 1938. They open 24 hours and serve a variety of foods typical of Bangka. In addition, tourist can also taste other typical culinary, such as Yellow Spice, Song Sui, fish crackers, Rusip, Calok, Lempok, Empek-empek, Kecalok, and Pekasem (Ibnu, 2016).

Yellow Spice is a special cuisine from Bangka Island. The basic ingredients of this food are marine fish. It can also use meat that gave various spices such as turmeric, onion, Lengkuas, and Terasi or Belacan typical of Bangka. Furthermore, Song Sui is Bangka special culinary which was cooked by using pork meat with pork innards mixed with red wine. Moreover, fish crackers are a food made from fish and wheat that make by sharing a form. It tastes almost the same as crackers.

Another traditional food is Rusip. It made from basic ingredients of bilis-fish (Mystacoleucus Padangensis) washed and sterilized, then mixed with a salt that balanced composition. Without heating process, added sugar liquid to make the aroma more noticeable, then it was stored until becoming ripe. This dough should be covered with a tight container to avoid mixing with any foreign object. In the past, usually this dough process is placed it in a narrow mouth urn. Room temperature must be maintained. This food can be cooked first or eaten directly with fresh vegetables. It can be an appetite lighter like a vitamin.

Another well-known traditional food is Calok. It made from fresh little prawns called rebon-shrimp. Shrimp are washed and mixed with salt as a preservative to last longer. Very suitable vegetable with warm rice dishes. It mixes with fresh vegetables, cucumbers, tomatoes and other fresh vegetables. This food is also delicious as a mixture of egg omelets. The next traditional food is 'Teritip'. This food is made from a kind of small oyster that lives on the beach. It attached to the rocks. The meat is very small and has a taste and texture like oysters in general. It usually eats fresh or salted with salt. Barnacles are very delicious added with red pepper and a kind of typical tamarind citrus.

Other traditional and popular food as appetizers is Lempok. This food is a kind of Dodol made from a mixture of granulated sugar and fruits. It usually consists of Cempedak, jackfruit and durian. The fruits used are softened to resemble the slurry, then mixed with the sugar in a 
certain ratio and heated over the fire until browned and easily formed. During heating, the mixture should always be stirred.

The typical food on this island is Empek-Empak shrimp. The food is made only by fishing communities living on the coast, such as in Belo-Laut Village, Muntok's District, West Bangka Regency. This food has a typical taste of shrimp and it is very rarely found in other areas that produce typical food.

The tourists can taste two extreme culinary typical islands of Bangka. Among others culinary, there is Kecalok and Pekasem. In addition to the taste of the extreme, this culinary-making way is guaranteed to make them amazed. It derived from marine animals, but the process of making this culinary-impressed unusual. The animals were fermented first. Enjoying culinary on the island of Bangka is not tired of his bored. There are just delicious foods from this region that are hard to find in other areas. In addition, Kecalok was made from anchovy, and shrimp Rebon which is also mixed with salt Gongseng and palm sugar. It tastes close to the taste of shrimp and comes from the same main ingredient.

In addition, there is another type of food namely "Pekasem." In contrast, this Bangka traditional food extreme one. It is hard to find in the store souvenirs or restaurants of the island of Bangka. It made from a kind of giant sea shells that are hard to find. Recently, the condition of the sea of Bangka Island was damaged by tin mining. In addition, it's also made of barnacles, a kind of sea animals such as shells attached to rocks of Bangka Island. Balancing this extreme culinary-culinary flavor, usually people of Bangka Island eat by mixing it with freshly squeezed orange juice, sliced onion, and sliced cayenne Pepper. In addition, it matched with various fresh vegetables. Its likes boiled cassava, cucumber or spinach, and other vegetables. The food will be better served as fried fish that is still hot.

Notwithstanding, there is an effort to improve environmental conditions by creating cleanliness and developing access to broad community education on fragile ecosystems. There are emergence efforts to care about environmental conditions namely Bangka environment creative activist of Kawa. They held a Volunteer Camp in the event program, those who are environmentally and teenagers' community. They focused on waste management activities along the coast of the islands. The chairman of the organization said many activities have been done by them in large scale activities, locally, and nationally. Volunteer Camp activities were held in collaboration with the management of Tanjung-Pesona beach, which aims to strengthen the relationship between activists and environmentalists. They also conduct surveys and data collection of potential waste points in coastal areas and the action of saving the coastal environment from waste. In addition, they also do a data collection of potential waste points of the clean coast. This will involve all the people and tourists who care about the coastal environment.

Furthermore, they managed to collect a garbage consisting of organic waste and inorganic waste to reduce carbon footprints. For non-recyclable organic waste, they planted out locations far from the coast and for inorganic waste such as plastics. It will be transported to their sustainable garbage bank headquarters located in Friendship Park of Sungailiat park. Enchantment Park for recycling, they actively supported by all people from all walks of life. 


\section{Macrothink}

Business and Economic Research

ISSN 2162-4860

2017, Vol. 7, No. 2

They consider positively and continue to follow every movement and community activities from the beginning until now. This activity proves that the island is still conserved by young people that can perform this creative activities (Vina, 2017).

However, the Coordinating Ministry for the Ministry of Marine Affairs assessed the determination of zoning of tin mining activities in the province of Bangka Belitung Islands. It becomes an urgent need of maintaining the carrying capacity of environmental coast. This is necessary to maintain the environmental quality of mining exploitation. Therefore, immediate regulation and realization through legal products in the form of regional regulations is required. He agreed to invite all stakeholders to agree to immediately resolve the issue related to the tin mines on the island. It's including local regulations will soon be realized. According to him, tin mining zoning plays an important role in solving the per tin conditions in the islands' province. Through zoning regulation, it is expected that tin governance of the future can be better. Therefore, the Minister coordinates all institutions related to the implementation of regulation of tin mining problem. In the zoning plan, they will be arranged for the tourism zone, the fishery conservation area, and the mining area. Zoning determination (Ima, 2016) shall be made on mutual commitment including the district heads who prefer the designated area. All have access to the maximum role of utilization of natural resources in the island can utilize the tourism sector, fisheries and mining.

\section{Conclusion}

This fieldwork results show that Tanjung-Pesona existing performance is in critical condition. There are three main issues that should be addressed immediately. Firstly, enhancing community education on handling fragile ecosystems. Secondly, local government gets to improve the performance of coastal's carrying capacity, as well as sustaining local business model. Thirdly, they get to increase an incentive for supporting coastal environment protection program that would reduce carbon footprints and made it based on collective action. It would maintain the levels of financial stability.

New finding of this study indicated that in terms of sustainable local-business models, there are many culinary options that can be found by tourists in Bangka Belitung. This culinary ecotourism would be other sustainable local-business models. It is unique traditional-culinary with specific taste and aroma.

So many coral reefs dead or damaged. It covered by liquid waste and tin mining waste. There is now an environmental improvement effort of the local government and young environmental activists to help restore the coastal environment. The final solution of the local government got to develop the zoning of tourism, and mining. In addition, there is the potential for regional culinary-ecotourism and fishing-ecotourism that can make a vibrant coastal-ecotourism in the islands.

\section{Implication}

Implementing ecotourism concept on Tanjung-Pesona Beach would improve conservation effort of the coastline. Besides, it would develop coastal environmental care to the local community. It's starting by cleaning the beach areas and managing the baggage along the 
beach. Evermore, they could develop culinary ecotourism by offering traditional food and its presentation. Nevertheless, the government would develop and aligned the coastal tourism management based on the concept. It would enhance the scenic quality of the beach and sustaining local economic and creating new jobs of serving coastal ecotourism activity.

\section{Limitations of the study}

This study has limited time and funding. There are still some research topics that can be done both in terms of coastal ecotourism in terms of demand and culinary ecotourism.

\section{Acknowledgment}

The author is pleased to acknowledge and to express an appreciation to the Editors for their generous comments and support during the review process to publish. The authors like to declare a million-thank to the anonymous reviewers for their helpful and constructive comments.

\section{Reference}

Ambalika, I., \& Septiawan, D. (2012). Exploration of Coral Reefs, University of Bangka Belitung. Retrieved from http://ubb.ac.id/indexkarang.php

Almeyda, A. M., Broadbent, E. N., Wyman, M. S., \& Durham, W. H. (2010). Ecotourism impacts in the Nicoya Peninsula, Costa Rica. Int. J. Tourism Res., 12, 803-819 https://doi.org/10.1002/jtr.797

Attemene, P., \& Eguavoen, I. (2017). Coastal ecotourism in The Gambia. Effects of sustainability communication on environments and rural livelihoods. ZEF Working Paper 154. Bonn http://www.zef.de/index.php?id=2213

Boscolo, S., Coppa, S., Falconi, A., Motta, E., Ferro, A., \& Baroni, A. (2011). Safeguarding of Venice Coastal Area Through Habitat@ Blocks. Journal of Coastal Research, 61, 269-273. https://doi.org/10.2112/SI61-001.25

Burke, L., Reytar, K., Spalding, M., \& Perry, A. (2011). Reefs at risk revisited. World Resources Institute: Washington, DC, 26-29

Burgera, J., O’Neillb, K. M., Handelc, S. N., Hensoldd, B., \& Fordd, G. (2016). The shore is wider than the beach: Ecological planning solutions to sea level rise for the Jersey Shore, USA, Landscape and Urban Planning, 157, 512-522.

https://doi.org/10.1016/j.landurbplan.2016.08.017

Chien, M. C. (2016). An empirical study on the effect of attractiveness of ecotourism destination on experiential value and revisit intention, Applied Ecology and Environmental Research, 15(2), 43-53. https://doi.org/10.15666/aeer/1502_043053

Cobbinah, P. B. (2015). Contextualising the meaning of ecotourism, Tourism Management Perspectives, 16, 179-189. https://doi.org/10.1016/j.tmp.2015.07.015

Cohen, J. (1960). A Coefficient of Agreement for Nominal Scales. Educational and 
Psychological, 20, 37-46. http://dx.doi.org/10.1177/001316446002000104

Diamantis, D. (2000). Ecotourism and sustainability in Mediterranean islands. Thunderbird Int'l Bus Rev, 42, 427-443.

https://doi.org/10.1002/1520-6874(200007/08)42:4<427::AID-TIE5>3.0.CO;2-G

Doyon, S., \& Sabinot, C. (2014). A New 'Conservation Space'? Protected Areas, Environmental Economic Activities and Discourses in Two Yucatán Biosphere Reserves in Mexico. Conservation \& Society, 12, 133-46. https://doi.org/10.4103/0972-4923.138409

Gottschalk, L. A. (2013). Content Analysis of Verbal Behavior: New Findings and Clinical Applications, Routledge, 19-22.

Gould, K. A. (2017). Ecotourism under pressure: The political economy of oil extraction and cruise ship tourism threats to sustainable development in Belize, Environment Sociology, 1-11. https://doi.org/10.1080/23251042.2017.1308238

Henderson, K. (1991). Dimensions of Choice: A Qualitative Approach to Recreation, Parks, and Leisure Research. Venture. State College. Australia.

Ibnu (2016). Enchantment tour of Bangka Belitung from culinary to its natural beauty, Ghibo.com. Retrieved from

http://ghiboo.com/2016/06/30/pesona-wisata-bangka-belitung-from-kuliner-so-beautiful-insti tute/

Ima (2016). Coordinating Ministry of Marine Affairs: Urgent Needs Mining Zone, Korankite. Retrieved from

http://www.korankite.com/kemenko-maritim-zonasi-tambang-keeds-mendesak/

Jenning, G. (2001). Tourism Research, John Willey \& Sons Australia, Ltd., 136-152

Kelkit, A., Celik, S., \& Esbah, H. (2010). Ecotourism potential of Gallipoli Peninsula historical national park, Journal of Coastal Research, 26(3), 562-568.

http://dx.doi.org/10.2112/09-1181.1

Khoiri, I., \& Indriasari, L. (2010). Threatened Beauty, Kompas. Retrieved from http://lifestyle.kompas.com/read/2010/03/23/16042070/keindahan.yang.terancam

Krause, A., \& Weir, E. (2011). Ecotourism: Management, Development and Impact, Nova Science Publishers. Hauppauge, New York

Lloret, J., \& Riera, V. (2008). Evolution of a Mediterranean Coastal Zone: Human Impacts on the Marine Environment of Cape Creus, Environmental Management, 42, 977-988. https://doi.org/10.1007/s00267-008-9196-1

Loperena, C. A. (2016). Honduras is open for business: extractivist tourism as sustainable development in the wake of disaster? Journal of Sustainable Tourism, 25(5), 618-633. http://dx.doi.org/10.1080/09669582.2016.1231808

Law, D. (2014). Uncovering the Beauty of Tanjung Pesona Beach in Bangka, seconds travel, 
Travel Detik. Retrieved from

https://travel.detik.com/dtravelers_stories/u-2463910/menyingkap-keindahan-pantai-tanjungpesona-di-bangka

Marwick, D. P., \& Uniger, C. H. (1975). The Sample Survey, Theory and Practice, Mc Graw Hill Book Co, New York.

Michael, W. (2017). Environmentally Friendly Industries: An Examination of Ecotourism as the Solution to the Environmental Degradation Caused by the International Tourism Industry. Honors Theses - Charlotte Campus. 4. http://scholarsarchive.jwu.edu/clt_honorstheses/4

Nouri, J., Danehkar, A., \& Sharifipour, R. (2008). Evaluation of ecotourism potential in the northern coastline of the Persian Gulf, Environment Geology, 55(3), 681-686.

https://doi.org/10.1007/s00254-007-1018-X

Nuzula, N. I., Armono, H. D., \& Rosyid, D. M. (2017). Management of Baluran National Park Resources for Coastal Ecotourism Based on Suitability and Carrying Capacity, Applied Mechanics and Materials, 862, 161-167.

https://doi.org/10.4028/www.scientific.net/AMM.862.161

Nikada (2011). Sungailiat Fisherman Urges Stop Sip Drive. Walhi. http://walhibangkabelitung.blogspot.co.id/2011/12/nelayan-sungailiat-desak-stop-kapal.html

Pace, N. L., \& Morgan, N. (2017). Living Shorelines: Eroding Regulatory Barriers to Coastal Resilience, Natural Resources \& Environment, 31(3), 44-47

Phillips, M. R. (2007). Beach Response to a Total Exclusion Barrage: Cardiff Bay, South Wales, UK. Journal of Coastal Research, 23(3), 794-805.

https://doi.org/10.2112/06-0746.1

Picard, D. (2007). Regional Strategic Action Plan for Coastal Ecotourism Development in the South Western Indian Ocean, Sustainable Development of Coastal Tourism in the South West Indian Ocean I: Potential and feasibilities of national and local development of coastal ecotourism, RECOMAP, 10-11.

http://www.commissionoceanindien.org/fileadmin/resources/RECOMAP\%20Reports/Potenti al_feasibilities\%20of\%20national\%20and\%20local\%20development_coastal\%20ecotourism. pdf

Picard, D. (2015). Making ecotourism sustainable: refocusing on economic viability. Lessons learnt from the "Regional strategic action plan for coastal ecotourism development in the South Western Indian Ocean," Journal of Sustainable Tourism, 23(6), 819-837. https://doi.org/10.1080/09669582.2015.1019512

Porter, B. A., Orams, M. B., \& Lück, M. (2015). Surf-riding tourism in coastal fishing communities: A comparative case study of two projects from the Philippines, Ocean \& Coastal Management, 116, 169-176. https://doi.org/10.1016/j.ocecoaman.2015.07.015

Sakata, H., \& Prideaux, B. (2013). An alternative approach to community-based ecotourism: a bottom-up locally initiated non-monetised project in Papua New Guinea, Journal of 


\section{Macrothink}

Business and Economic Research

ISSN 2162-4860

2017, Vol. 7, No. 2

Sustainable Tourism, 21, 880-899. http://dx.doi.org/10.1080/09669582.2012.756493

Vina (2017). BECAK Babel Care for the Environment Do Clean Trash on the Beach, Kabarbabel. Retrieved from

http://www.kabarbabel.com/2017/01/13/becak-babel-peduli-lingkungan-lakukan-bersih-samp ah-di-pantai/

Virapart, C. (2011) Tsunami Prevention and Preparedness Practices for Tourism Sector and Private Entrepreneur in Khao Lak, Phang Nga Province of Thailand. Journal of Coastal Research, 61, 365-368. https://doi.org/10.2112/SI61-001.40

Whitney, M. (2017). Environmentally Friendly Industries: An Examination of Ecotourism as the Solution to the Environmental Degradation Caused by the International Tourism Industry, Honors Theses, Charlotte Campus. 4. Retrieved from

http://scholarsarchive.jwu.edu/clt_honorstheses/4

Yanuar, H. (2017). Tourism Becomes Indonesia's Largest Foreign Exchange Donor Year 2020, Liputan6. Retrieved from

http://lifestyle.liputan6.com/read/2824692/pariwisata-jadi-penyumbang-devisa-terbesar-indon esia-tahun-2020

\section{Copyright Disclaimer}

Copyright for this article is retained by the author(s), with first publication rights granted to the journal.

This is an open-access article distributed under the terms and conditions of the Creative Commons Attribution license (http://creativecommons.org/licenses/by/3.0/). 